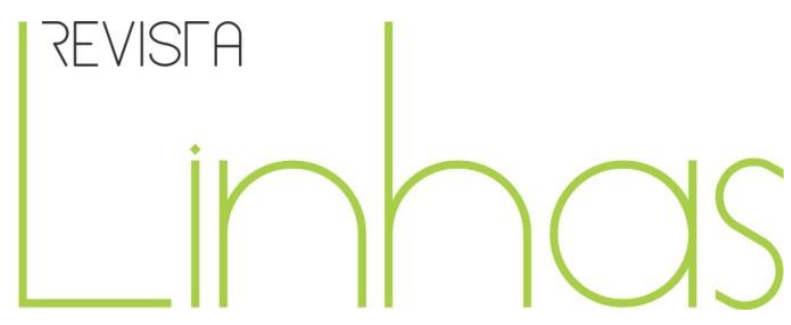

\title{
The politics of history textbooks in South African classroom in the era of Curriculum 2005
}

\begin{abstract}
South Africa has recently celebrated twenty years of political transition from apartheid government to a democratic nation. One of the important changes in this transition was the reform of classroom curriculum, including the nature of textbook content taught in postapartheid South African schools. This article discusses the textbook content in the era of Curriculum 2005, a national curriculum statement introduced in 1997 and subsequently revised in 2002. First, I discuss the socio-political history of education in South Africa, including the transition from apartheid to post-apartheid as a context to this analysis. Second, I describe the limitations of history textbooks content taught in post-apartheid classrooms. Using critical theory, I argue that the content of newly adopted history textbooks did not radically interrupt the long-standing misrepresentation and underrepresentation of the political histories of marginalized groups in South Africa, although some textbooks have made progress than others.
\end{abstract}

Keywords: History Textbooks. South Africa. Post-Apartheid. Curriculum 2005. Critical Theory.

\author{
Bekisizwe Ndimande \\ University of Texas at San \\ Antonio - UTSA - \\ San Antonio/Texas - United \\ States
}

bekisizwe.ndimande@utsa.edu

\footnotetext{
Para citar este artigo:

NDIMANDE, Bekisizwe. The politics of history textbooks in South African classroom in the era of Curriculum 2005. Revista Linhas. Florianópolis, v. 19, n. 41, p. 139-159, set./dez. 2018.
}

\footnotetext{
${ }^{1}$ Curriculum 2005 is the new national curriculum framework that was introduced after the abolishment of apartheid education system in South Africa in 1994.
} 


\title{
A política dos livros didáticos de história nas salas de aula sul- africanas na era do Curriculum 2005
}

\begin{abstract}
Resumo
A África do Sul celebrou recentemente vinte anos da transição política do regime de apartheid para uma nação democrática. Uma das mudanças importantes nesta transição foi a reforma curricular, incluindo a natureza do conteúdo dos livros didáticos ensinado nas escolas Sul-Africanas pós-apartheid. Este artigo discute o conteúdo dos livros didáticos na era do Curriculum 2005, uma declaração nacional curricular introduzida em 1997 e posteriormente revista em 2002. Primeiramente, discuto a história sócio-política da educação na África do Sul, incluindo a transição do apartheid para o pós-apartheid como um contexto para esta análise. Em segundo lugar, descrevo as limitações de conteúdo dos livros didáticos de história, ensinado nas salas de aula pós-apartheid. Usando a teoria crítica, argumento que o conteúdo dos livros adotados recentemente não interrompeu de forma decisiva a histórica deturpação e sub-representação da história política de grupos marginalizados na África do Sul, embora alguns livros tenham feito mais progressos do que outros.
\end{abstract}

Palavras-chave: Livros Didáticos de História. África do Sul. Pós-Apartheid. Curriculum 2005. Teoria Crítica. 


\section{Introduction}

South Africa emerged from decades of colonial and apartheid rule only twenty four years ago. This nation of 52 million people suffered one of the worst political divide and political repression through the system called apartheid. As a result, the era of apartheid also produced social inequalities that would exist for many years to come. Black, Indians, and Coloureds were at the receiving end of these inequalities and thus were treated as second class citizens. All socio-economic programs were designed to create disparities along racial lines. Access to opportunities of social mobility was purely based on race. Education came to play a major role in this kind of social engineering. For instance, under apartheid public schools were not only segregated by race, the funding allocation between White and non-White schools was grossly unequal. The purpose was to maintain racial hierarchy which ensured that non-White populations continue to be second-class citizens. In addition, the curriculum content represented what Apple (1993) calls the "hidden curriculum and the effects of textbooks" in order to advance the apartheid ideology. Needless to say, apartheid led to fierce political resistance from the oppressed groups, which the government suppressed with repressive military brutalities.

It was only in 1994 that South Africa held its first democratic elections, in which President Rolihlahla Nelson Mandela was elected as president. It is undeniable that the introduction of democracy in this nation was a partial victory, especially to those of the marginalized groups who were historically oppressed by the colonial and apartheid systems. Changes in the education sphere were even more important for the purpose of providing better educational opportunities and to improve living conditions of many people who were impoverished under apartheid. While these socio-political changes were important for education, they were far from complimentary. As I argue in this article, there were some limitations and challenges that came along with curriculum and textbook reform.

For the purpose of this article, I focus on the politics of textbook content in the era of curriculum reform as guided by Curriculum 2005. I have framed my arguments into several parts. First, I discuss the history of education in South Africa as was implemented during apartheid, including the political transition from apartheid to post-apartheid. Second, I discuss Curriculum 2005, including its limitation in curriculum reform. I analyze 
textbook content to illustrate some limitation and some improvement of such textbook content taught in classrooms, particularly for students from the historically marginalized groups. Third, I draw on critical theory to make claims that textbooks void of critical content may be geared toward protecting the colonial status quo, especially in nations with the history of colonialism and human oppression. Based on the history textbooks content I evaluated, I conclude that the content of the history textbooks adopted after apartheid and curriculum reform did not radically interrupt the long-standing misrepresentation and underrepresentation of the political histories of marginalized groups in South Africa.

\section{Education Context under Apartheid South Africa}

Apartheid was institutionalized in South Africa in 1948. it was a hegemonic government system designed to enforce racial segregation and the institutionalization of White supremacy (BIKO, 2002; LODGE, 1983; MARKS \& TRAPIDO, 1987; MOTHLABI, 1985). For instance, apartheid legislated and enforced racial categories and a racially segregated society. This government system created four racial categories which were also stratified in terms of their relations to the social structures. The term Black was used to refer to the Indigenous peoples of South Africa, Coloured, the peoples of mixed race, Indian, the peoples who were brought to South Africa from India in the 1800 s by the British colonial government to work as indentured slaves in the sugar cane fields, and White, those who originally came from Europe and other Western countries during the colonization of South Africa from the early 1600s. This racial classification under apartheid guaranteed that white supremacy and privilege in South Africa were maintained, while Blacks, Indians, and Coloured people were treated as second-class citizens. 


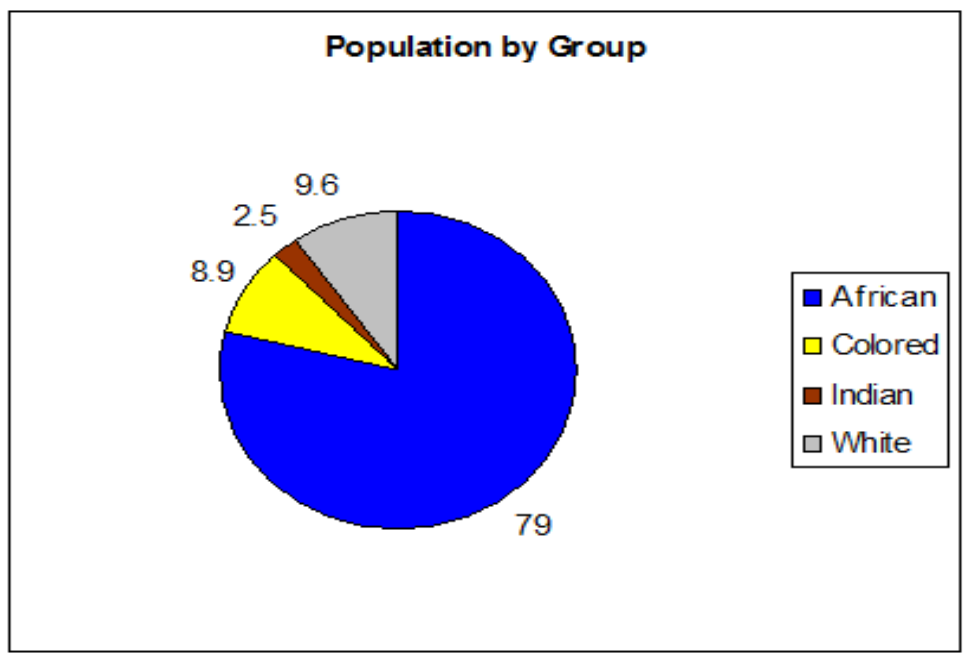

Figure 1 - Graphic with population by group - africans, colored, indian and white people Source: By the author

Under apartheid, education came to play a major role in carrying out these social inequalities. Hendrik Frensch Verwoerd, Minister of Native Affairs in 1950 and Prime Minister in 1958, introduced the Bantu Education bill at the white-only parliament. Bantu Education was a system of education offered to black people. The distinction between Bantu Education and apartheid education follows: whereas apartheid education lumped together the oppressive education system "offered" to Blacks, Coloured, and Indians collectively, Bantu Education was specifically “offered” only to black peoples through the Department of Native Affairs, that was later renamed the Department of Bantu Education. Verwoerd believed that black people should be subjugated through education to enforce the apartheid ideology. In analyzing Bantu Education, Christie and Collins (1984) assert that this system of education was by far the most repressive education system South Africa has ever experienced:

[It] stipulated that all black schools would have to be registered with the government, and that registration would be at the discretion of the Minister. This measure enabled the government to close any educational programmes which did not support its aims... The Act gave wide powers to the Minister of Bantu Education, including control over teachers, syllabuses [syllabi], and any other matter relating to the establishment, maintenance, management and control over government Bantu schools. (CHRISTIE; COLLINS, 1984, p. 171) 
Christie and Collins (1984) further explain that, by 1959, virtually all Black schools (except for the few Catholic schools) had been brought under the central control of the Native Affairs Department and operated in accordance to the laws of Bantu Education.

Bantu Education was indeed the Ideological State Apparatuses (ALTHUSSER, 1971) used during apartheid to maintain the status quo of racial discrimination and social inequalities, marginalizing black South Africans for many years to come. The curriculum content represented what Enslin (1990) called "Fundamental Pedagogics" to describe biased curriculum and textbook content imposed on black classrooms and on black teacher preparation programs in other to suppress and undermine critical thinking. It was no surprise that black students had a disproportionately high dropout rate during this time. According to Hartshorne (1992), in 1988 alone, 307,000 black students left school, having gone no further than grade four, and approximately 440,000 did not study beyond grade seven. $^{2}$

This system continued for many years, but there was also resistance against apartheid. The anti-apartheid struggle was also witnessed in the education struggle for better curriculum. The late 1980 s and the early 1990 s were pivotal years for gradual change toward democracy. As I discuss elsewhere (NDIMANDE, 2012), after the 1994 democratic elections, the post-apartheid government instituted a democratic Constitution (1996), which called for a series of progressive changes with the goal of redressing the previous inequalities created by the apartheid regime. In addition, the South African Schools Act (SASA) of 1996 was passed to repeal all forms of apartheid schooling legislation and replace it with a uniform school system that supports the democratic transformation of the South African society and combats racism, sexism, and all other forms of discrimination (SASA, 1996, 2A-3). The goal was to be achieved by instituting a uniform, non-racial system of education in terms of school organization, governance, funding, including the curriculum aspects such as the choice of textbooks and textbook content.

At the center of all these democratic changes was the implementation of Curriculum 2005, the new national curriculum framework whose goal was to address

\footnotetext{
${ }^{2}$ For an in-depth discussion of apartheid and Bantu education, see Kallaway (1984).
} 
these long standing inequities in curriculum content and pedagogy, including the adoption of new textbooks.

\section{Curriculum 2005 and Curriculum/Textbook Reforms}

Just over a year after the South African Schools Acts of 1996 was announced, Sibusiso Bhengu, the former minister of education, launched a new curriculum framework known as Curriculum 2005 in 1997, which was modeled on Outcomes Based Education. Indeed Curriculum 2005 was meant to be an ideal substitution for the racist and colonialist curriculum, which dominated the majority of South African classrooms for decades. In addition, Curriculum 2005 framework was the new government's effort toward democratization of public education, including classroom room curriculum and adoption of different textbooks. This was for the purpose of redressing the educational inequalities of the previous apartheid education system. Many educators, students, and parents, particularly those in Black, Coloured, and Indian schools and communities, welcomed the new curriculum framework with applause. I argue elsewhere that such excitement was quite understandable in a country where the majority of citizens bore the brunt of education inequalities (NDIMANDE, 2000).

However, the excitement brought by the announcement of Curriculum 2005 was short-lived. After its initial implementation in 1997/98, the new framework had lots of challenges in terms of meeting the goals for which it was intended to achieve. The problem was that the new curriculum framework was largely modelled on Outcomes Based Education. It is rooted in the belief that "outcomes" can be a measure of accountability and a means of evaluating the quality and impact of teaching (NDIMANDE, 2010). This resulted in a serious criticism that shows how Curriculum 2005, modelled on "outcomes," follows a neoliberal market approach to curriculum reform. As Lubienski and Ndimande (2017) argue, neoliberal market mechanism in curriculum reform has negative impact on equity, particular its failure to overcome historical injustices in education. Public school policies and curriculum models that are influenced by neoliberal ideology can perpetually marginalize historically disadvantaged communities, in this case, Blacks, Coloureds and Indian communities in South Africa. In fact, I agree with Jansen's (1999) claim that this outcomes based model of curriculum framework failed to bring 
sufficient positive historical legacy to post-apartheid curriculum reform. ${ }^{3}$

Few years later the criticism of Curriculum 2005 and its outcomes based characteristics put the government under enormous pressure to form a Task Team called Curriculum 2005 Review Committee for the streamlining of Outcomes Based Education and its implication (CHISHOLM, 2000). Even so, the focus of the review team was not to evaluate the adverse impact of OBE. The team focused on simplifying the learning outcomes rather than interrogating the philosophy of the policy, especially the curriculum content (NDIMANDE, 2010).

\section{The Politics of Curriculum and Textbooks Content in Post-Apartheid South Africa}

I begin this section by acknowledging some partial victories accomplished in the post-apartheid education reforms. For instance, some schools have desegregated, schools funding has increased in public schools that were historically underfunded, Curriculum 2005 was introduced to replace apartheid curriculum policies. Althou8gh all these changes have not fully improved the education circumstances of marginalized communities and their children, they are nonetheless some education changes in the right direction, hence I call them partial victories because under apartheid education, Black, Coloured and Indian students faced bleak educational opportunities. In this section, however, I to attention the limitations and challenges of curriculum and textbook content that was evident in the new curriculum framework. I specifically examine the content of textbooks in early post-apartheid reforms. I argue that the content of the textbook in early post-apartheid curriculum reform in essence produced a biased historical knowledge skewed towards the dominant group and the colonial ideology as oppose to radically interrogating the untold histories of political domination. I argue that such textbook content fail to interrupt the long-standing misrepresentation and underrepresentation of political histories of marginalized groups in South Africa.

The first history textbook content I analyze in this article was used in the early years of post-apartheid curriculum reform, i.e. after the introduction of Curriculum 2005.

\footnotetext{
${ }^{3}$ For a detailed criticism of Outcomes Based Education in South Africa, see Jansen \& Christie, 1999.
} 
The textbook content under discussion was represented in the syllabus titled, History Syllabus, Higher Grade Standard 8-10, which was distributed by the Ministry of Education in 2000. Let me hasten to clarify that my review of this history textbook content was not a research study. I was on an informal visit to Ematsheni Secondary School ${ }^{4}$ in the beginning of Fall 2001 academic year. While I was on their campus, I was struck by the textbook content, which I analyze for critical content.

In reviewing the History Syllabus, Higher Grade Standard 8-10, as it resembles the history textbook content, I found that it was not as critical a text to be suitable for postapartheid classroom. The history textbook content was divided into two sections, namely the General and South African history. The first section, which is the general history, constitutes the "almighty" European/U.S. history - with focus including Lenin, Stalin, Roosevelt 's new Deal, Monroe Doctrine, International Relations, Cold War, and so forth. Again, I do not mean to argue that such history is unnecessary, but it would make the content critical if, for example, the textbook would give an analysis of how Lenin or Roosevelt might be related to South African politics and/or how had these European figures shaped the politics of the world to an extent that it impacted South Africa. During apartheid education, all history textbooks started with European history. This needs to be problematized. A question needs to be asked about the structure of the textbook content. Indeed it becomes ideologically suspicious when European/U.S. history content gets allotted the first section in the textbook. This is suspicious for two reasons. First, it assumes that European/U.S. history is better than the Indigenous South African history. Second, it gives ample time for European/U.S. history to be taught to the end, while the South African section is rushed through as the semester nears the end.

A separate theme called Africa since the World War II raised more concerning questions: Why would a textbook begin African history at this particular period? This was approximately the period of decolonization of Africa. How would students know about the struggles of the colonized countries during the colonial era if colonialism itself was documented as gloss over? As a compromise, the text mentions, superficially of course, movements for independence in Africa and the rise of nationalism as a way of

\footnotetext{
${ }^{4}$ The name of the school is fictitious. Indeed this was also the same school where I conducted my student teaching when I was studying to become a teacher.
} 
introduction to the theme. This is nothing other than undercutting the importance of such history. The history textbook must be critical, especially in a country like South Africa that was colonized by the British and the Dutch, this colonial history must be taught in a critical discussion so that students can understand the history of race and racial oppression that continue to exist in South African.

It is important to also point out that whether or not the purpose of the theme was to talk about Africa since the World War II, a representative history textbook has to lay out a historical and political context on how African societies were shaped by colonial powers and colonialism (before and after World War II). Not to talk about or even allude to such events is tantamount to a total misrepresentation of African thought and philosophy. Also striking is the fact that while the textbook talks about the de-colonization of Africa, there is no language of colonial critique. The textbook language gives a misleading impression as if the de-colonization of Africa was a free gift. There is very little mention of the struggle of women and men who put a gallant fight that exerted pressure on colonialism. Further, the textbook talks about the common challenges facing the independent African states, yet does not mention the existing neo-colonialism in those "former" colonized states. Should students be barred from learning about the effects of neo-colonialism, which by the way has assumed a new form, namely, the privatization and marketization of the state? I argue that unless history is taught critically, students will be denied to be engaged with the historical events in a critical manner.

There is notable omission of important African history in this textbook, for example, the discussion of slave trade from Africa to Europe and the Americas is missing. In A People's History of the United States, Howard Zinn (2005) writes that "slavery existed in the African states and it was sometimes used by the Europeans to justify their own slave trade" (p. 27). As Zinn further points out that African slavery was terrible and need not to be praised. However, he argues, it was far different from plantations or mining slavery in the Americas which was life-long crippling. By 1800 , Zinn documents that 10 to 15 million blacks form Africa had been transported to Europe and the America:

First the Dutch, then the English, dominated the salve trade. (By 1795 Liverpool had more than a hundred ships carrying slaves and accounted for half of all the European slave trade.) Some Americans in New England 
entered the business, and in 1637 the first American slave ship, the Desire, sailed from Marblehead... It is roughly estimated that Africa lost 50 million human beings to death and slavery in those centuries... at the hands of slave traders and plantation owners in Western Europe and America, the countries deemed the most advanced in the world. (ZINN, 2005, p. 29)

This history narrated by Haward Zinn must be considered important in a country like South Africa which was colonized by both the Dutch and the British, yet it is missing in the high school history textbook.

As I mentioned above, the South African history appears in the second part of the text. The first part this history covers the period 1924 to 1948. It concentrates on such topics as white political parties and white-only elections, economic policies, recognition of Afrikaans, great depression, Hertzog's racial policies, effects of the World War I on South African politics, labor unrest, and 1948 elections among other topics. With the African National Congress in existence as early as 1912, and with the active anti-apartheid mobilization, for example the Defiance Campaign of 1953, it is yet another omission in the history content on South Africa. One of the problems in such history content that starts with Europeans in South Africa (white political parties and white-only elections) is the assumption that the history of South Africa began with the arrival of the European colonialists. This is the mainstream history that offers only the dominant narrative. Ndimande and Neville (2015) argue that a history of South Africa that begins with the arrival of the Dutch and the British is problematic:

The nation that has become known as South Africa today has existed for thousands of years before the "discovery" by Europe. Pre-colonial South Africa was populated by various Indigenous groups who migrated from East to Central Africa, the hunter gatherer societies who eventually made it to the southern tip of the continent. The arrival of the European colonialists to set up the Cape Colony was the beginning of colonial conquest and the usurping of Indigenous land. (p. 4)

The South Africa history section also has the period 1976 to 1994. The discussion of this period in the text resembles an add-on history, i.e. a history discussion with no substance, but to add some few events here and there with neither depth nor critical 
engagement. Worse still, the instructions on the history syllabus read the following: "2.3 The period 1976 to 1994 (Not for examination purposes)" which meant students were not to be examined on this theme. Given the significance of this period in the history of South African politics, a period of worldwide campaign against apartheid, how could it be treated as an add-on? Once treated as an add-on, and not required for examination purposes, this implies that students will not be rigorously engaged in this particular history. Apple (1996) refer to this kind of curriculum content as a "selective tradition," meaning that only the content deemed necessary by the dominant group could be selected to be taught and/or emphasized in the curriculum. In the South African context, it shows how the history textbook even after apartheid were still dominated by and based on white philosophy and perceptions. Textbooks that are racially biased reflect one of the tendencies of neo-colonialism - a tendency that attempts to erase the collective memory of oppressed peoples. It needs also to be pointed out that it is ironic when the events leading to 1994 democratic elections and beyond are treated as add-on history in South African classrooms, yet these events were receiving national and international, especially after President Mandela was elected the first democratic president.

It needs to be mentioned here that the appalling textbook content situation in South African classrooms in the post-apartheid era finally caught the attention of the former Minister of Education three years after the post-apartheid textbook adoption. Former Minister of Education, Kader Asmal, subsequently set a two-year deadline for a new set of history textbooks, including one on apartheid. In addition to this two-year deadline, Kader Asmal launched the South African History Project to oversee the process of transforming the history teaching in all schools (MTSHALI, 2002). While the ministry needs to be commended for the effort to transform history textbook content, the project was completed with minimum improvement in the content for critical history of South Africa. In other words, while some textbook content added some important topics, none of these were as critical for conscientizing students about their identities and sociopolitical struggles, as history supposed to accomplish. Let me use two eaxamples to elabotare on this point.

The first example is from the 2007 textbook that was adopted after the South African History Project was completed. The title of the textbook is New Generation History 
Grade 12. The structure of the content in this book is concerning because the history of Europe is right at the beginning. I have argued earlier in this article about the implications of a South African history textbook that begins with the history of European countries, rather than national history. This shows the dominant role the European discourse plays in the curriculum in South African classrooms. But most importantly, like the previous book analyzed in this paper, this history text omitted the atrocities of the history of colonization, including slavery in the Cape Colony (MOLTENO, 1984) and in Africa (ZINN, 2005). The section of Civil Society Protest is a problematic section because it starts with Civil Societies in the US and Europe protesting various wars and oppression. The protests against apartheid are the placed towards the end of this section and the events are vaguely discussed. The fact that the title such as Apartheid and Anti-Apartheid movement is missing, is in itself problematic in that there seem to be an unwillingness to name apartheid by name.

This second example is the adopted textbook titled, Viva History Learner's Book Grade 10. This particular text book brings a glimmer of hope in the transformation of history content. There are a number of newly included critical topic that relate to the socio-economic and political contexts of South Africa. In the first chapter there is a unit on Indigenous African knowledge, followed by the "impact of European conquest, warfare, and early colonialism in the Americans, Africa, and India, including a unit on slave trade. The content in this book differs in that the structure does not follow the dominant structure that begins the history of South Africa with the arrival of Europeans. The critique of the display of the body of the Khoisan woman's body, Sarah Baartman by the British colonizers, who transported her statue to England in 1810 (HORNER; HATTINGH; VAN SCHALKWYK; SELLO, 2005) to publicly display an African woman with large buttock, is not only an objectification of women bodies, but the bodies of those who were colonized. This is one of the few history textbooks I have come across so far that are willing to delve in such a critical content to help student learn about how the history represented them, especially those from the marginalized communities. As the authors of this book wrote in the jacket cover, this book "addresses the Eurocentric view of Africa's history." 


\section{Critical theory as a lens to analyze textbook content}

For the purpose of my analysis of problems of textbook content in South Africa, I draw on critical theory and critical scholars to understand the impact on this situation on communities. Critical theory is a broad field that includes contributions from the Frankfurt School, Marxist and neo-Marxist traditions, Theories of Democracy, Feminist Tradition, Postcolonial Theories, among others (POPKEWITZ, 1999; TORRES, 1999). While critical theory identifies, associates, and traces its original roots to the German Marxist Frankfurt School in the 1920s, its uses and evolution challenged the essentializing and biased analyses and frameworks in the social sciences. ${ }^{5}$ In this article I use the term critical theory as situated within the educational field context which gained momentum in the early 1970 s and throughout the 1990 s in the United States and Europe, which had an influence on educational scholars in other countries as well. Critical theory in this discussion is informed by the work of intellectuals and theorists such as Gramsci, 1971; Freire, 1970; Althusser, 1971; Apple, 1979; Young, 1975; Giroux, 1983; McLaren, 1995; Popkewitz, 1995; Torres, 1999, among others. I argue that critical analysis is necessary and crucial in this discussion about textbook content in order to bring policy changes in school curriculum that can be more oriented toward social justice and advocate for inclusiveness in classroom curriculum.

Drawing on critical theory lens, Apple (1996) reminds us that education is not a neutral phenomenon. "It is produced out of cultural, political, and economic conflicts, tensions, and compromises that organize and disorganize a people" (p. 22). Thus, we need to ask serious questions about whose knowledge is included or excluded in history textbooks. Parents and individuals from dominant groups tend to have influence on school policy by virtue of the political and economic power they possess thus excluding marginalized groups (APPLE, 1996). The discussion in this article, from apartheid curriculum and textbook content in the Curriculum 2005 is an example of how curriculum content is a contestation that reproduces tensions that organize and disorganize people. Such tension manifests itself through textbook adoption and content (CORNBLETH; WAUGH, 1995).

\footnotetext{
${ }^{5}$ See Torres (1999), especially on p. 91.
} 
For many decades, the history of classroom curriculum in South Africa and in other nations such as United States, Brazil, Namibia, the United Kingdom, has been characterized by a curriculum content that has produced and reproduced social inequalities (APPLE, 1979; BOWLES \& GINTIS, 1976; FREIRE, 1970; GIROUX, 1983; KALLAWAY, 1984; NKOMO, 1990; YOUNG, 1971; ZEICHNER AND DAHLSTROM, 2001). The school curriculum, in its biased and colonialist textbooks, used the content of the curriculum to exclude the voices of the subaltern (SPIVAK, 1988), that is those who are outside the sociocultural and political hegemony of the colonial empires, this subjugated and colonized. In other words, the curriculum content, mainly through textbooks, adhered to and followed rigidly the transmission of the canon. This canon was supposed to be consumed by students uncritically and unchallenged as if this knowledge represented the universal "truth" for all students in the classroom. Apple (1993), Lowen (1995), Zinn (2005) and others argue that the knowledge production itself was problematic, as was the case with school textbook content which created canons of "truths" and historical distortions taught and accepted without much debate in the classroom. By and large these have been the dispositions of the mainstream curriculum which lacked or failed to recognize the historically marginalized groups as well as fail to acknowledge the different socio-political contexts in which public schools exist (Ibid.)

Michael Apple's analysis on the on the politics of curriculum content is helpful to unpack elements of dominant control in what he calls refers to Textbook content as a form of curriculum control. According to Apple (1993), it is through textbooks that the "official knowledge" of the school is pronounced. His analysis on the politics of textbooks helps us understand that the content of school textbooks is surrounded by controversies over what is included and excluded in texts:

Texts are really messages to and about the future. As part of curriculum, they participate in no less than the organized knowledge system of society. They participate in creating what society has recognized as legitimate and truthful. They help set the canons of truthfulness and, as such, also help recreate a major reference point for what knowledge, culture, belief, and morality really are. Yet such statement... is basically misleading in many important ways. For it is not a "society" that has created such texts, but specific groups of people. (APPLE, 1993, p. 49) 
I need to point out that one of the theoretical influences in the struggles against apartheid education in South Africa was the scholarship of Paulo Freire. Although his ground-breaking book, Pedagogy of the Oppressed, was banned in South Africa in the 1970 s and 1980s, as it was in Brazil at some point while he as in exile, his ideas were able to reach South Africa nonetheless ${ }^{6}$. As one of the prominent scholars in the critical tradition, Paulo Freire (1970), writes about problematic curriculum content and pedagogy that tends to marginalize oppressed groups, just like the Blacks, Coloureds, and Indians that were historically marginalized in South Africa. He argues that the curriculum of the oppressed is characterized by biased knowledge toward the ruling class, i.e. it is biased toward the dominant groups who control the curriculum content, including textbooks.

Using critical theory as a lens, Freire argues that a school curriculum devoid of historical or distorted reality has led to the dehumanization of people, people who are "made" to lose a sense of their history and identity. This serves to create a stratified society where power is not shared equally among communities. In this context, argues Freire, the rulers are found, those he called the oppressors, subjugating others, those he called the oppressed.

Because of these pervasive inequalities, Freire makes a strong case that students whose knowledge is not represented in the textbooks and in curriculum content may perceive themselves as less legitimate and undeserving of leadership roles, and to be more precise, they lose their sense of identity and history. This perpetuates ignorance about their socio-economic and political conditions. On the contrary, Freire proposes liberatory education that engages students to challenge the curriculum content and create critical possibilities to change the world. Liberatory education does not omit certain histories or provide biased historical content to the oppressed group and their communities, but helps them to support broader struggles for cultural, political, economic, gender, and social recognition.

In Pedagogy of the Oppressed, Freire states that the pedagogy of the oppressed is the pedagogy of people engaged in the fight for their own liberation. Here is one of Freire's crucial tenets about education for critical; curriculum for social justice:

\footnotetext{
${ }^{6}$ See Nekhwevha, 2002.
} 
No pedagogy which is truly liberating can remain distant from the oppressed by treating them as unfortunates and by presenting for their emulation models from among the oppressors. The oppressed must be their own example in the struggle for their redemption. (FREIRE, 1970, p. 39)

Schools should be places for socio-political, economic, and intellectual independence, not dehumanize those with less power and treat them as objects. In this context, history textbooks have a duty to interrogate the dichotomy of subjects versus objects on curriculum and pedagogy so that educators and students can equally engage in the classroom learning. Students in particular should be encouraged to be critical thinkers, thus get involved in what Freire called the processes of "reading the world."

\section{Conclusion}

The discussion about history textbook content in post-apartheid South Africa shows that the content is far from complimentary. It shows that nations that have emerged from a long history of political oppression, including the denial of educational opportunities, can struggle in their curriculum reform process. In this case, the sociopolitical context has created what Ladson-Billings (2006) calls "education debt," which means that unless a concerted effort is made to transform the curriculum, it would hard to overcome a curriculum that misrepresents the knowledge and history of Indigenous people in that nation. The introduction of Curriculum 2005 was a step in the right direction, yet this post-apartheid national curriculum framework failed to adopt textbooks that interrogate this biased history. The only textbook that tried to do unravel the colonial history brings a glimmer of hope. Indeed scholars in the critical tradition can help with ideas about empowering textbook curriculum content, thus incorporate the history of historically marginalized communities as well as bring it to the center of the history textbooks. 


\section{Acknowledgements}

I would like to thank the editorial team of the Revista Linhas for translating this article from English to Portuguese, including their diligent proofreading in both languages. I would also like to thank the anonymous reviewers. I am grateful to Eliane Peres, Chris de A. Ramil, Vera Lúcia Gaspar da Silva and Karla Cristina F. P. Koerich, who motivated me to write and submit this manuscript for peer-review in this journal.

\section{References}

ALTHUSSER, Louis. Lenin and philosophy and other essays. New York, NY: Monthly Review Press, 1971.

APPLE, Michael Whitman. Cultural politics and education. New York: Routledge, 1996.

APPLE, Michael Whitman. Ideology and curriculum. London: Routledge and Kegan Paul, 1979.

APPLE, Michael Whitman. Official knowledge: Democratic education in a conservative age. New York: Routledge, 1993.

BIKO, Steve. I write what I like: Selected writings. Chicago, IL: The University of Chicago Press, 2002.

BOWLES, Samuel and GINTIS, Herbert. Schooling in capitalist America: Educational reform and the contradictions of economic life. United States of America: BasicBooks, 1976.

CHISHOLM, Linda. C2005 and the Policy Process. Paper presented at the Kenton Education Association. Port Elizabeth, South Africa, October 26, 2000.

CHISHOLM, Linda. Continuity and change in education policy research and borrowing in South Africa. In: KALLAWAY, Peter (Ed.). The History of education under apartheid 1948 - 1994: The doors of learning and culture shall be opened. South Africa: Pearson Education, 2002. p. 94-108.

CHRISTIE, Pam; COLLINS, Colin. Bantu Education: Apartheid ideology and labour reproduction. In: KALLAWAY, Peter (Ed.). Apartheid and education: The education of black South Africans. Johannesburg, South Africa: Ravan Press, 1984. p. 160-183. 
Constitution of the Republic of South Africa. As adopted on May 8, 1996, and amended on October 11, 1996. Retrieved from:

<http://www.justice.gov.za/legislation/constitution/SAConstitution-web-eng.pdf>. CORNBLETH, Catherine; WAUGH, Dexter. The great speckled bird. New York: St. Martin's Press, 1995.

DEPARTMENT OF EDUCATION. Curriculum 2005. Learning for the 21st Century. Pretoria. 1997.

ENSLIN, Penelope. The role of fundamental pedagogics in formulation of educational policy in South Africa. In: KALLAWAY, Peter (Ed.). Apartheid and education: The education of Black South Africans. Johannesburg: Ravan Press, 1984, p. 139-147.

FREIRE, Paulo. Pedagogy of the oppressed. New York: The Continuum Publishing Corporation, 1970.

GIROUX, Henry A. Theory and resistance in education: A pedagogy for the opposition. South Hadley, MA: Bergin \& Garvey, 1983.

GOVENDER, S.; MNYAKA, M.; PILLAY, G. New Generation History Grade 12. Durban: New Generation Publishers, 2007.

HARTSHORNE, Ken. Crisis and challenge: Black education 1910-1990. Cape Town, South Africa: Oxford University Press, 1992.

History Syllabus (2000) (Higher Grade), Standard 8-10. [Ministry of Education, South Africa].

HORNER, E. A.; HATTINGH, L.; VAN SCHALKWYK, D.; SELLO, B. Viva History: Learner's Book Grade 10. Florida Hills, South Africa: Vilvia Publishers, 2005.

JANSEN, Jonathan D. Why outcomes-based education will fail: An elaboration. In: JANSEN, Jonathan D.; CHRISTIE, Pam (Eds.). Changing curriculum: Studies on outcomesbased education in South Africa. Kenwyn, South Africa: Juta \& Co. Ltd, 1999. p. 145-156.

JANSEN, Jonathan D; CHRISTIE, Pam (Eds.). Changing curriculum: Studies on outcomesbased education in South Africa. Kenwyn, South Africa: Juta \& Co. Ltd., 1999.

KALLAWAY, Peter (Ed.). Apartheid and education: The education of Black South Africans. Johannesburg, South Africa: Ravan Press, 1984.

LADSON-BILLINGS, Gloria. From the Achievement Gap to the Education Debt:

Understanding Achievement in U.S. Schools. Educational Researcher, v. 35, n. 7, p. 3-12, 2006.

LODGE, Tom. Black politics in South Africa since 1945. London, England: Longman, 1983.

LOEWEN, James W. Lies my teacher told me. New York: Simon \& Schuster, 1995. 
LUBIENSKI, Christopher; NDIMANDE, Bekisizwe S. The politics of market mechanisms in education. In: NDIMANDE, Bekisizwe S.; LUBIENSKI, Christopher (Eds.) Privatization and the education of marginalized children: Policies, impacts and global lessons. New York: Routledge, 2017. p. 3-16.

MARKS, Shula; TRAPIDO, Stanley (Eds.). The politics of race, class, and nationalism in the twentieth century South Africa. London, England: Longman, 1987.

MOLTENO, Frank. The Historical Foundations of the Schooling of Black South Africans. In: KALLAWAY, Peter (Ed.). Apartheid and education: The education of Black South Africans. Johannesburg: Ravan, 1984, p. 45-107.

MOTLHABI, Mokgethi Buti George. The theory and practice of Black resistance to apartheid: A social-ethical analysis. Johannesburg, South Africa: Skotaville, 1985.

MTSHALI, Thokozani. South Africa is losing its memory: Revisiting apartheid throws up the challenges of teaching history in a new way. Sunday Times, October 13, 17, 2002.

NDIMANDE, Bekisizwe S. From Bantu education to the fight for socially just education, Equity \& Excellence in Education, 46 (1), p. 20-35, 2013.

NDIMANDE, Bekisizwe S. Neoliberalism and teacher struggles in post-apartheid public schools. In: VERMA, Rita (Ed.). Be the change: Teacher, activist, global citizen. New York: Peter Lang, 2010. p. 275-288.

NDIMANDE, Bekisizwe S. Perspectives on South African Curriculum 2005. In: AERA/Special Interest Group, Research Focus on Education in the Caribbean \& Africa, J (2), p. 2-3, 2000.

NDIMANDE, Bekisizwe S. Race and resources: Black parents' perspectives on postapartheid South African schools. Race Ethnicity and Education, 15 (4), p. 525-544, 2012.

NDIMANDE, Bekisizwe S.; NEVILLE, Helen. A. Urban education and Black racial identity in South Africa. Urban Education, 2015.

NEKHWEVHA, Fhulu. The influence of Paulo Freire's "Pedagogy of Knowing" on the South African Education Struggle in the 1970's and 1980's. In: KALLAWAY, Peter (Ed). The history of education under apartheid 1948-1994: The doors of learning and culture shall be opened. Cape Town: Maskew Miller Longman, 2002. p. 134-144.

Nkomo, Mokubung (Ed.). Pedagogy of domination: Toward a democratic education in South Africa. Trenton, New Jersey: Africa World Press Inc., 1990.

POPKEWITZ, Thomas S. Introduction: Critical traditions, modernism, and the 'posts.' In: POPKEWITZ, Thomas S.; FENDLER, Lynn. (Eds.). Critical theories in education: Changing terrains of knowledge and politics. New York: Routledge, 1999. p. 1-13. 
SOUTH AFRICAN SCHOOLS ACT. Government Gazette of the Republic of South Africa, $n$. 84 of 1996, v. 377, November 15, 1996.

SPIVAK, Gayatri Chakravortry. Can the subaltern speak? In: NELSON, Cary; GROSSBERG, Lawrence (Eds.). Marxism and the interpretation of culture. Urbana: University of Illinois Press, 1988. p. 271-313.

YOUNG, Michael F. D. Knowledge and control: New direction for the sociology of education. London: Collier-Macmillan, 1975.

ZEICHNER, Kenneth; DAHLSTROM, Lars. (Eds.). Democratic teacher education reform in Africa: The case of Namibia. Windhoek, Namibia: Gamsberg Macmillan, 2001.

ZINN, Howard. A People's history of the United States: 1492-Present. New York: Harper Collins Press, 2005. 